\title{
KEMAMPUAN REPRESENTASI MATEMATIS PESERTA DIDIK BANGKINANG DALAM MENYELESAIKAN SOAL PISA 2015
}

\author{
Zulfah $^{1}$, Wida Rianti ${ }^{2}$ \\ 1,2 Universitas Pahlawan Tuanku Tambusai, Jl. Tuanku Tambusai No 23 Bangkinang \\ Email penulis pertama: zulfahasni670@gmail.com
}

\begin{abstract}
The purpose of this study was to describe the mathematical representation ability of Bangkinang students in completing the 2015 PISA problem. The research approach used was qualitative research. The instrument used in this study was a test in the form of a 2015 PISA question, an open interview guide, and the value of students. Data analysis techniques are carried out namely reducing data, presenting data, and verifying data or drawing conclusions from the data held. Based on the data analysis of the 2015 PISA questions categorized as mathematical representation, the questions are number 10,11, 14, 16, 25, 31, 38, and 39 obtained some information. The ability of visual representation of table presentation, students have been able to re-present data or information from a table into other forms such as row patterns. In this representation there are various forms or patterns that are given to show good visual representation capabilities. Visual image representation ability where students draw geometric parts to solve problems and facilitate problem solving. The ability of symbolic representations or mathematical equations or expressions possessed by students is already owned by most students. Based on the analysis of the answer sheets on questions categorized as verbal representations obtained verbal abilities (words or written texts) that are owned as large as students are good. These students have been able to write the steps of completion well and regularly. Based on the analysis of the students' answer sheets, it is known that the problem which is also categorized as a problem solving problem students have difficulty in making problem situations based on the data or representation given and making equations or mathematical models of the given representation.
\end{abstract}

Keywords: The ability of mathematical representation, PISA 2015

\begin{abstract}
Abstrak
Tujuan penelitian ini adalah mendeskripsikan kemampuan representasi matematis peserta didik Bangkinang dalam menyelesaikan soal PISA 2015. Pendekatan penelitian yang digunakan yaitu penelitian kualitatif. Instrument yang digunakan pada penelitian ini adalah tes berupa soal PISA 2015, pedoman wawancara yang sifatnya terbuka, dan nilai peserta didik. Teknik analisis data yang dilaksanakan yaitu mereduksi data, penyajian data, dan verifikasi data atau penarikan kesimpulan dari data yang dimiliki. Berdasarkan analisis data dari soal PISA 2015 yang dikategorikan soal representasi matematis yaitu soal nomor 10, 11, 14, 16, 25, 31, 38, dan 39 diperoleh beberapa informasi. Kemampuan representasi visual dari penyajian tabel, peserta didik sudah mampu menyajikan kembali data atau informasi dari suatu tabel menjadi bentuk lain seperti pola barisan. Pada representasi ini terdapat bermacam bentuk atau pola yang diberikan sehingga menunjukkan kemampuan representasi visual yang baik. Kemampuan representasi visual gambar dimana peserta didik membuat gambar bagian-bagian geometri untuk menyelesaikan permasalahan dan memfasilitasi penyelesaian masalah. Kemampuan representasi simbolik atau persamaan atau ekspresi matematika yang dimiliki peserta didik sudah dimiliki hampir sebagian peserta didik. Berdasarkan analisis lembar jawaban pada soal yang dikategorikan representasi verbal diperoleh kemampuan verbal (kata-kata atau teks tertulis) yang dimiliki sebagai besar peserta didik sudah baik. Peserta didik tersebut sudah mampu menuliskan langkah-langkah penyelesaian dengan baik dan teratur. Berdasarkan analisis lembar jawaban peserta didik, diketahui pada soal yang juga dikategorikan soal pemecahan masalah peserta didik mengalami kesulitan dalam membuat situasi masalah berdasarkan data atau representasi yang diberikan serta membuat persamaan atau model matematis dari representasi yang diberikan.
\end{abstract}

Kata Kunci: Kemampuan representasi matematis, soal PISA 2015 
Kemampuan representasi matematika merupakan salah satu kemampuan matematika yang harus dimiliki oleh siswa. NCTM mengemukakan bahwa salah satu dari lima standar yang mendeskripsikan keterkaitan antara pemahaman dan kompetensi matematik siswa adalah kemampuan representasi matematika (NCTM, 2000). Representasi matematika yang merupakan salah satu kompetensi adalah suatu aspek yang selalu hadir dalam pembelajaran matematika. Kemampuan representasi adlah suatu kemampuan matematika dengan pengungkapan ide-ide matematika (masalah, pernyataan, definisi, dan lain-lain) dalam berbagai cara (Syafri, 54: 2017). Representasi atau model dari suatu situasi atau konsep matematika jika disajikan dalam bentuk yang sudah jadi sesungguhnya dapat dipandang telah mengurangkan atau meniadakan kesempatan bagi siswa untuk berpikir kreatif dan menemukan sejak awal konsep matematika yang terkandung dalam suatu situasi masalah. Mustangin (2015) menyatakan bahwa ragam representasi yang sering digunakan dalam mengkomunikasikan matematika antara berupa sajian visual seperti table, gambar, grafik; pernyataan matematika atau notasi matematika; dan teks tertulis yang ditulis daengan bahasa sendiri baik formal maupun informal, ataupun kombinasi semuanya. Hal serupa diungkapkan Neria dan Amit (2004) yang menyatakan bahwa ragam representasi yang sering digunakan dalam mengkomunikasikan matematika antara lain: table, gambar, grafik, pernyataan matematika, teks tertulis, ataupun kombinasi dari semuanya. Pembelajaran matematika dikelas sebaiknya memberikan kesemptan yang cukup bagi siswa untuk melatih dan mengembangkan kemampuan representasi matematis (Sabirin, 2014). Aspek representasi matematis dapat dilihat pada Tabel 2.3 berikut.

Tabel 2.3

Aspek Representasi Matematis

\begin{tabular}{|c|c|c|}
\hline No & Aspek Representasi & Bentuk-bentuk Operasional \\
\hline \multirow[t]{3}{*}{1} & Representasi Visual & \\
\hline & Grafik, diagram, atau tabel & $\begin{array}{l}\text { 1. Menyajikan kembali data atau informasi dari suatu representasi } \\
\text { grafik, diagram, atau tabel } \\
\text { 2. Menggunakan representasi visual untuk menyelesaikan masalah }\end{array}$ \\
\hline & Gambar & $\begin{array}{l}\text { 1. Membuat gambar pola-pola geometri } \\
\text { 2. Membuat gambar bangun-bangun geometri untuk menjelaskan } \\
\text { masalah dan memfasilitasi penyelesaian }\end{array}$ \\
\hline 2 & $\begin{array}{l}\text { Representasi Simbolik } \\
\text { (Persamaan atau ekspresi } \\
\text { matematis) }\end{array}$ & $\begin{array}{l}\text { 1. Membuat persamaan atau model matematis dari representasi } \\
\text { yang diberikan } \\
\text { 2. Membuat konjektur dari suatu pola bilangan } \\
\text { 3. Penyelesaian masalah dengan melibatkan ekspresi matematis }\end{array}$ \\
\hline 3 & $\begin{array}{l}\text { Representasi Verbal (Kata-kata } \\
\text { atau teks tertulis) }\end{array}$ & $\begin{array}{l}\text { 1. Membuat situasi masalah berdasarkan daa atau representasi yang } \\
\text { diberikan } \\
\text { 2. Menuliskan interpretasi dari suatu representasi } \\
\text { 3. Menuliskan langkah-langkah penyelesaian masalah matematika } \\
\text { dengan kata-kata } \\
\text { 4. Menyusun cerita yang sesuai dengan suatu representasi yang } \\
\text { disajikan } \\
\text { 5. Menjawab soal dengan menggunakan kata-kata atau teks tertulis }\end{array}$ \\
\hline
\end{tabular}

Sumber: Sumarmo, 2017 
Rubrik skala penilaian tingkat kemampuan representasi peserta didik dapat dilihat pada

Tabel 2.4.

Tabel 2.4

Rubrik Skala Penilaian Tingkat Kemampuan Representasi

\begin{tabular}{|c|c|c|c|}
\hline \multirow{2}{*}{$\begin{array}{l}\text { Aspek } \\
\text { representasi }\end{array}$} & Skor & & \\
\hline & 1 & 2 & 3 \\
\hline \multirow{2}{*}{$\begin{array}{l}\text { Representasi } \\
\text { Visual }\end{array}$} & $\begin{array}{l}\text { 1. Tidak menyajikan } \\
\text { kembali data atau } \\
\text { informasi dengan } \\
\text { tepat } \\
\text { 2. Tidak menggunakan } \\
\text { representasi visual } \\
\text { untuk menyelesaikan } \\
\text { masalah }\end{array}$ & $\begin{array}{l}\text { 1. Menyajikan kembali } \\
\text { sebagian data atau } \\
\text { informasi dari suatu } \\
\text { representasi grafik, } \\
\text { diagram, atau tabel } \\
\text { 2. Menggunakan } \\
\text { representasi visual yang } \\
\text { sebagian sudah tepat } \\
\text { untuk menyelesaikan } \\
\text { masalah }\end{array}$ & $\begin{array}{l}\text { 1. Menyajikan } \\
\text { kembali data atau } \\
\text { informasi dari suatu } \\
\text { representasi grafik, } \\
\text { diagram, atau tabel } \\
\text { 2. Menggunakan } \\
\text { representasi visual } \\
\text { untuk } \\
\text { menyelesaikan } \\
\text { masalah }\end{array}$ \\
\hline & 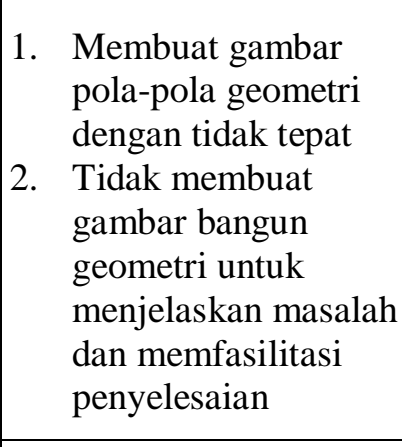 & $\begin{array}{l}\text { 1. Membuat gambar pola- } \\
\text { pola geometri yang } \\
\text { hampir tepat } \\
\text { 2. Membuat gambar bangun } \\
\text { geometri yang hampir } \\
\text { tepat untuk menjelaskan } \\
\text { masalah dan } \\
\text { memfasilitasi } \\
\text { penyelesaian }\end{array}$ & 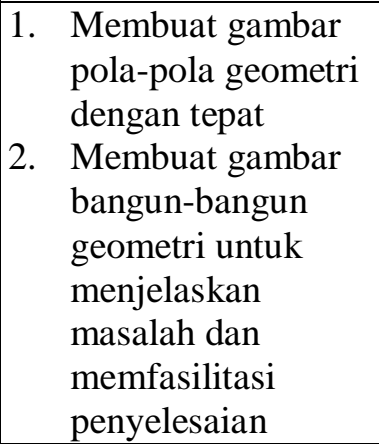 \\
\hline $\begin{array}{l}\text { Representasi } \\
\text { Persamaan } \\
\text { atau ekspresi } \\
\text { matematis }\end{array}$ & 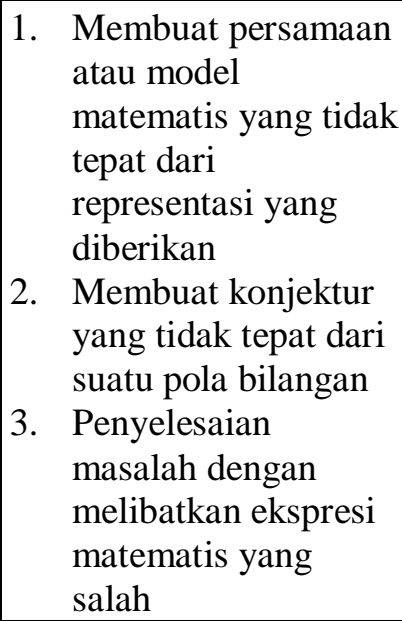 & 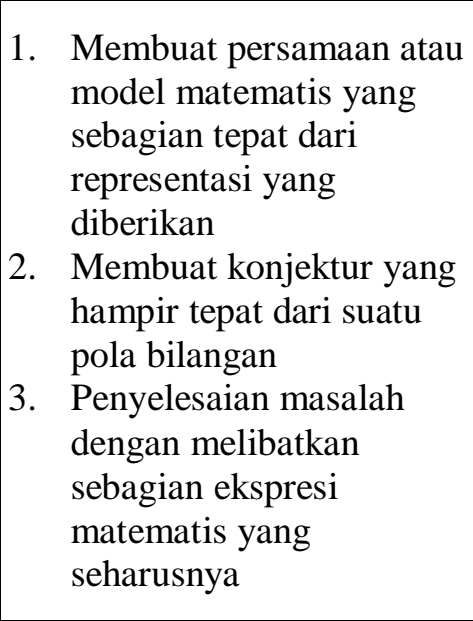 & 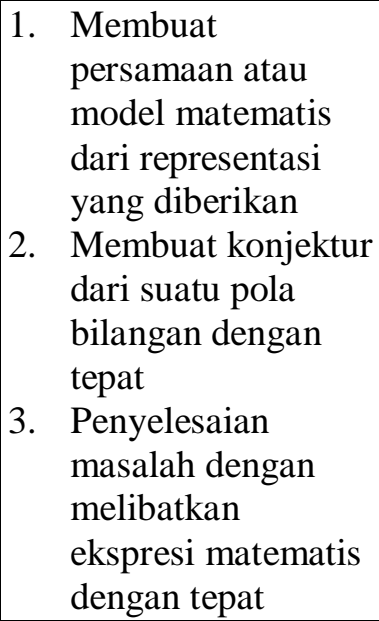 \\
\hline $\begin{array}{l}\text { Representasi } \\
\text { Kata-kata atau } \\
\text { teks tertulis }\end{array}$ & 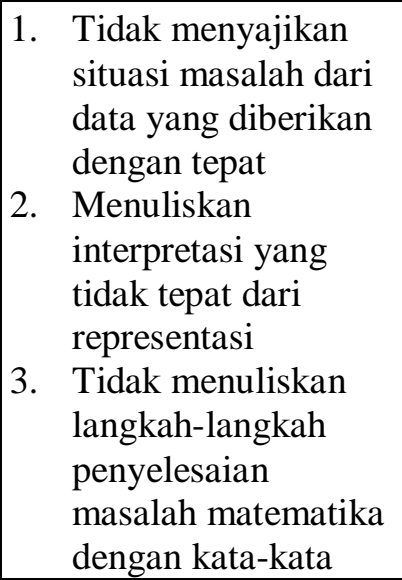 & 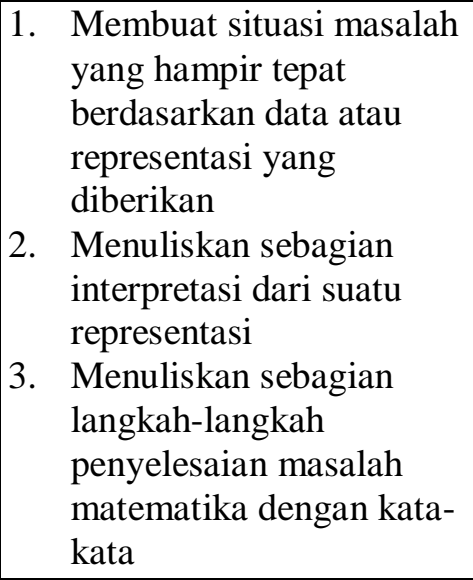 & 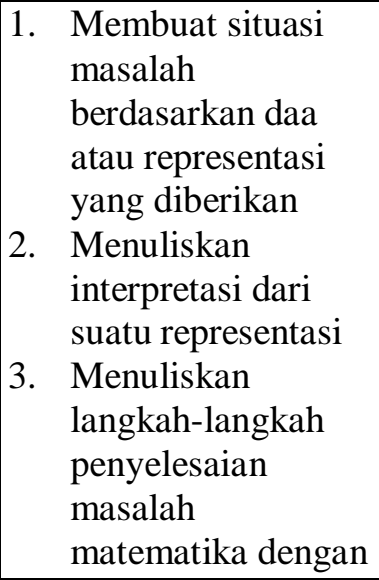 \\
\hline
\end{tabular}




\begin{tabular}{|l|l|ll|l|}
\hline & $\begin{array}{l}\text { 4. } \begin{array}{l}\text { Menjawab soal } \\
\text { dengan } \\
\text { menggunakan kata- } \\
\text { kata atau teks tertulis }\end{array} \\
\text { 4anjawab soal dengan } \\
\text { menggunakan kata-kata } \\
\text { atau teks tertulis }\end{array}$ & $\begin{array}{l}\text { kata-kata } \\
\text { 4. }\end{array}$ & $\begin{array}{l}\text { Menjawab soal } \\
\text { dengan } \\
\text { menggunakan kata- } \\
\text { kata atau teks } \\
\text { tertulis }\end{array}$ \\
\hline
\end{tabular}

Pentingnya kemampuan representasi matematis bagi peserta didik, membuat peneliti tertarik untuk menganalisi kemampuan representasi matematis peserta didik di Bangkinang. Kemampuan representasi matematis peserta didik ditinjau dengan pemberian soal PISA 2015 yang sudah divalidasi oleh pakar dan praktisi. Melalui penelitian ini guru, peneliti ataupun pihak terkait dapat menjadikan hasil penelitian sebagai dasar dalam memilih strategi dalam peningkatan kemampuan representasi matematis peserta didik. Peneliti berikutnya juga dapat menjadikan sebagai latar belakang penelitian berikutnya.

\section{METODE}

Metode penelitian yang digunakan yaitu pendekatan deskriptif. Peneliti melakukan analisis terhadap hasil tes berupa soal PISA 2015 kepada 120 orang peserta didik SMP Negeri 1 Bangkinang Kota dan SMP Negeri 2 Bangkinang Kota Tahun Ajaran 2017/2018. Analisis data dilaksanakan dengan mendeskripsikan data yang telah dikumpul melalui tes dan wawancara tanpa membuat kesimpulan yang berlaku umum atau generalisasi (Sugiyono, 2010). Teknik analisis data yang dilaksanakan yaitu mereduksi data, penyajian data, dan verifikasi data atau penarikan kesimpulan dari data yang dimiliki. Berdasarkan analisis data dari soal PISA 2015 yang dikategorikan soal representasi matematis yaitu soal nomor $10,11,14,16,25,38$, dan 39 diperoleh beberapa informasi.

\section{HASIL DAN PEMBAHASAN}

Kemampuan representasi matematis merupakan salah satu tujuan dari pembelajaran matematika di sekolah. Kemampuan ini erat kaitanyanya dengan kemampuan komunikasi dan pemecahan masalah. Untuk dapat mengkomunikasikan sesuatu, sesorang perlu representasi baik berupa gambar, grafik, diagram, maupun bentuk representasi lainnya (Sabirin, 33: 2014). Kemampuan representasi matematis sama halnya dengan kemampuan komunikasi matematis, namun yang membedakannya adalah permintaan dari soal yang memang meminta menuliskan langkah dari penyelesaian soal. Soal PISA 2015 yang dikategorikan sebagai soal representasi matematis adalah soal nomor 10, 11, 14, 16, 25, 31, 38, dan 39 .

\section{Analisis Soal No 10}

Pada soal nomor 10 ada banyak beberapa cara penyajian kembali tabel ke bentuk lainnya. Banyak peserta didik yang menggunakan pola barisan dalam memecahakan permasalahan tersebut, hal ini dikarenakan peserta didik sudah mempelajari materi barisn dan deret. Pola barisan yang disajikan juga bermacam-macam. Cuplikan representasi peserta didik sebagai berikut. 


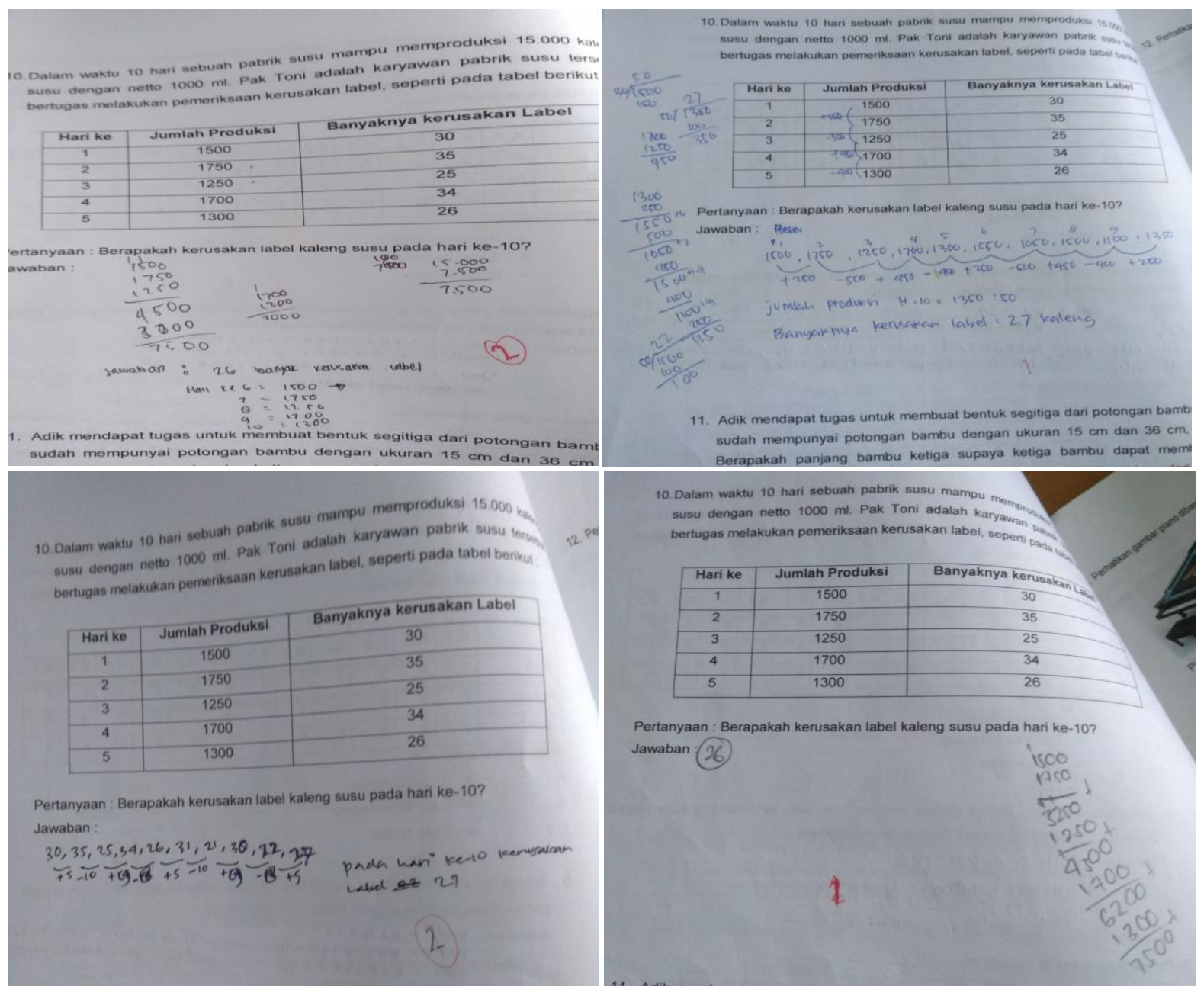

\section{Gambar 5. Cuplikan Lembar Jawaban Peserta Didik untuk Soal No 10}

Berdasarkan analisa lembar jawaban 78 orang peserta didik mampu menyajikan kembali data atau informasi dari suatu representasi tabel, sehingga diperoleh skor tinggi yaitu 3, 13 orang pesertadidik menyajikan kembali sebagian data atau informasi namun tidak sampai pada tahap penyampaian kesimpulan. Sedangkan 29 peserta didik tidak menjawab soal tersebut sehingga nilainya 0 dan berada di kategori rendah. Melalui wawancara, diperoleh informasi bahwa 29 orang peserta didik tersebut bingung dan tidak tau bagaimana cara menentukan jumlah produksi kesepuluh dan banyaknya kerusakan label.

\section{Analisis Soal No 11}

Soal nomor 11 mengarahkan peserta didik untuk mampu membuat gambar bangun-bangun geometri untuk menyelesaikan masalah dan memfasilitasi penyelesaian permasalahan. Soal tersebut dapat memfasilitasi peserta didik untuk menunjukkan kemampuan representasi gambarnya. Dari 120 orang peserta didik, 84 orang peserta didik menggunakan rumus pythagoras untuk menentukan sisi ketiga dari sebuah segitiga, ada yang menjumlahkan atau mengurangkan kuadrat dari kedua sisi untuk menentukan sisi ketiga. Sehingga diperoleh nilai yang tinggi yaitu 3. 23 orang peserta didik memperoleh nilai rendah yaitu 1 . Pada 23 orang pesertadidik tersebut 8 orang peserta didik hanya 
menerka-nerka jawaban dari permasalahan yang diberikan sehingga tidak satupun yang memperoleh penyelesaian yang tepat. Ada juga peserta didik yang menggunakan sifat segitiga sama kaki, dan menyampaikan sisi ketiga yaitu $15 \mathrm{~cm}$ atau $36 \mathrm{~cm}$, dan peserta didik juga tidak memperoleh penyelesaian yang tepat. Selebihnya yaitu 13 orang peserta didik melakukan percobaan terhadap data yang diperoleh, dan terdapat peserta didik yang memperoleh jawaban yang tepat dan ada juga peserta didik yang tidak menemukan solusi dari permasalahan. Maka total peserta didik yang memperoleh nilai tinggi yaitu sebanyak 92 orang 28 orang memperoleh nilai rendah yaitu 1. Cuplikan lembar jawaban peserta didik pada soal nomor 11 adalah sebagai berikut.

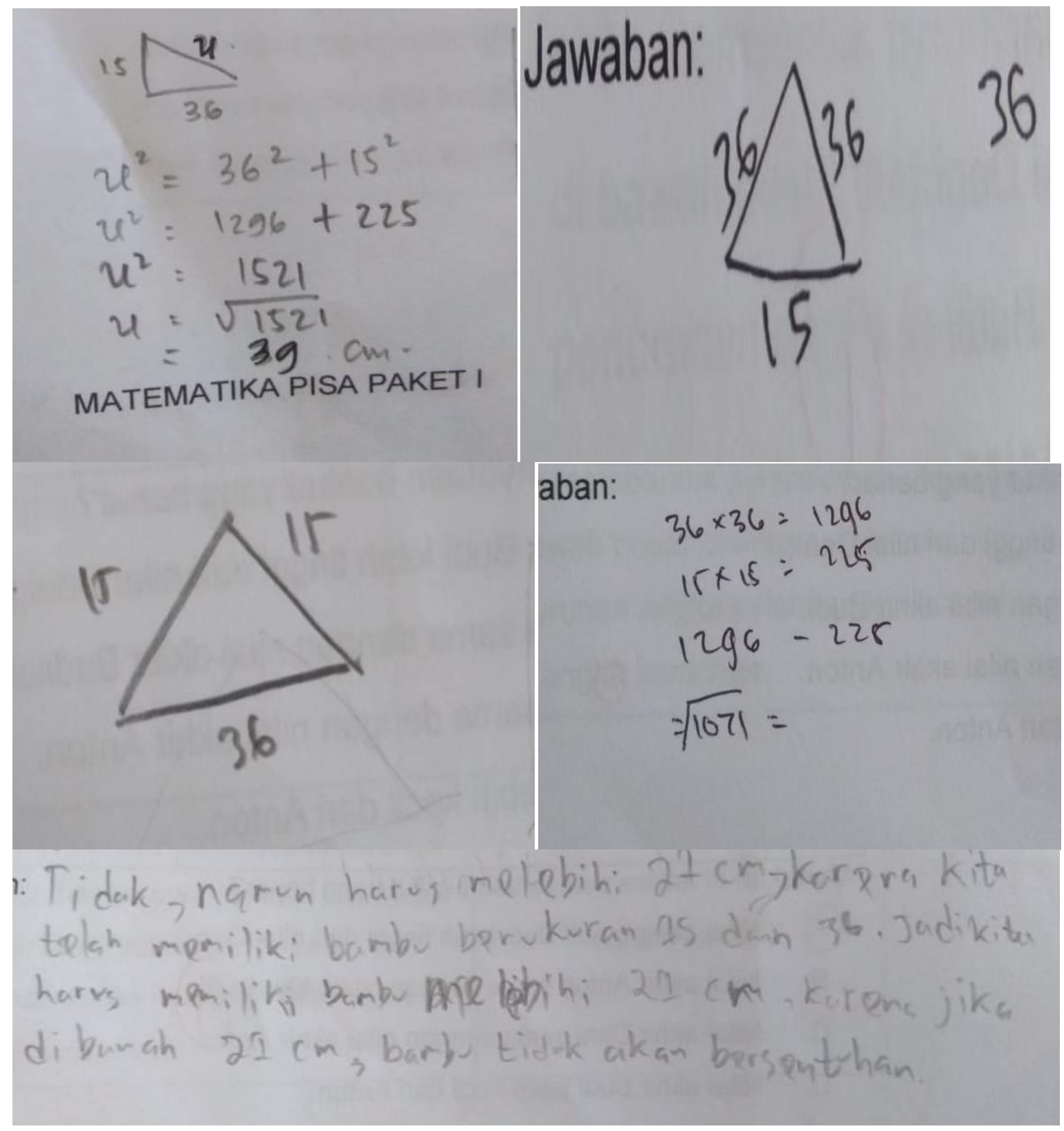

Gambar 6. Cuplikan Lembar Jawaban Peserta Didik pada Soal No 11 


\section{Analisis Soal No 16}

Soal nomor 16 termasuk kedalam soal yang mampu meninjau kemampuan representasi katakata atau teks tertulis. Peserta didik diminta untuk membuat situasi masalah berdasarkan data atua representasi yang diberikan, menuliskan interpretasi data, menuliskan langkah-langkah penyelesaiannya dengan kata-kata, dan menjawab soal dengan kata-kata atau teks tertulis seperti yang ada pada indikator representasi kata-kata atau teks tertulis. Pada soal ini, rata-rata peserta didik SMP Bangkinang sudah mampu membuat situasi masalah berdasarkan data yang diberikan. Peserta didik sudah mampu menuliskan langkah-langkah penyelesaian dengan baik. Peserta didik terlebih dahulu menentukan jumlah lembar uang yang diambil di ATM 1 dan jumlah lembar uang di ATM 2, karena diketahui uang yang diambil total adalah 15 lembar. Kemudian mengalikan banyak lembaran tadi dengan nilainya. Dan menjumlahkan jumlah uang yang mungkin diambil dari keduaATM. Dari 120 orang peserta didik hanya 6 orang yang keliru dalam melakukan perhitungan menentukan jumlah lembar uang pada ATM 2, dan 3 orang tidak menjawab soal tersebut.

\section{Analisis Soal No 25}

Berdasarkan data yang diberikan pada soal nomor 25 berupa sekeping ubin yang mempunyai motif, sebagaian besar peserta didik dapat menyusun kembali 4 ubin yang mempunyai pola yang sama dengan tepat. 113 orang peserta didik dapat menentukan susunan keempat ubin yang mempunyai pola yang sama dengan tepat.

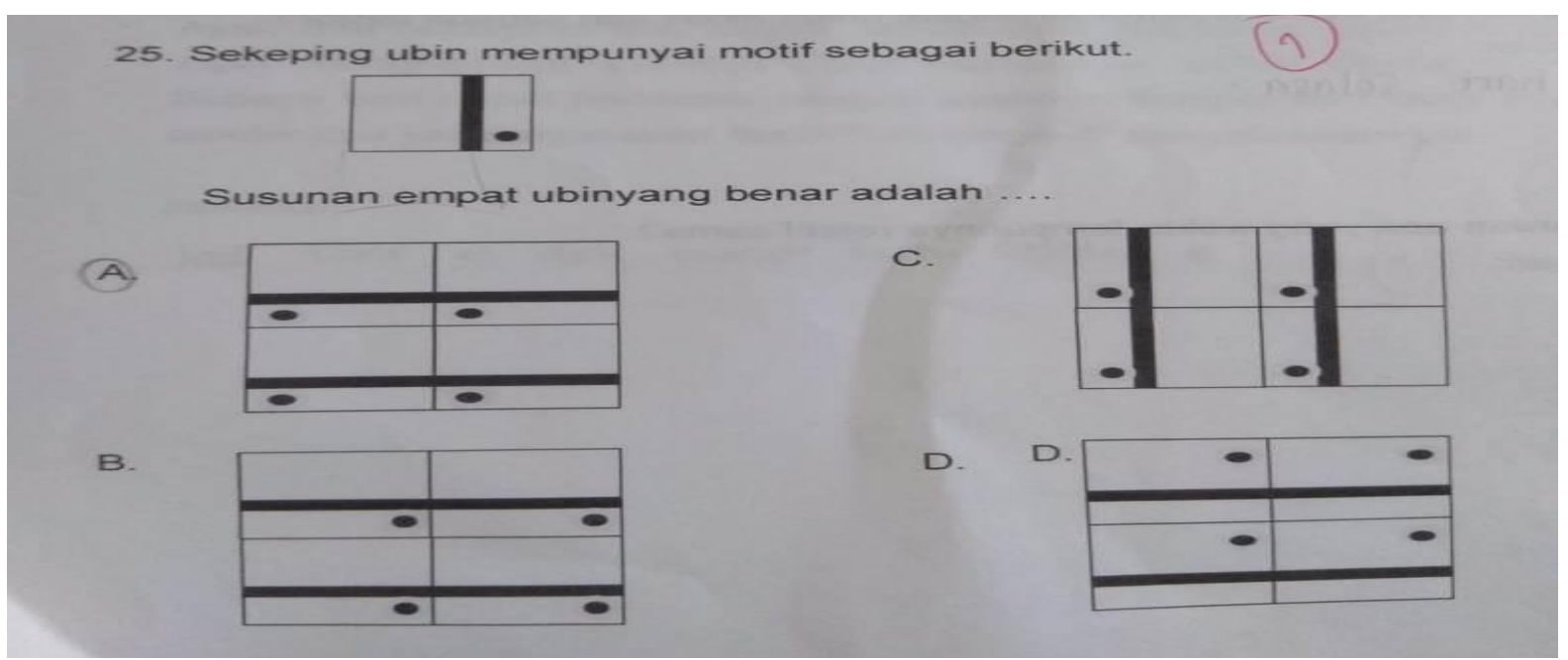

Gambar 7. Cuplikan Lembar Jawaban Peserta Didik Soal No 25

\section{Analisis Soal No 31}

Soal nomor 31 selain soal yang dikategorikan soal komunikasi matematis, peneliti dan para pakar juga mengkategorikan sebagai soal yang mengarahkan peserta didik untuk membuat representasi berupa ekspresi matematika atau model matematika. Berdasarkan jawaban yang diberikan, 50 orang peserta didik mampu menjawab soal dengan baik, dan 70 orang peserta didik tidak memberikan jawaban yang tepat. 


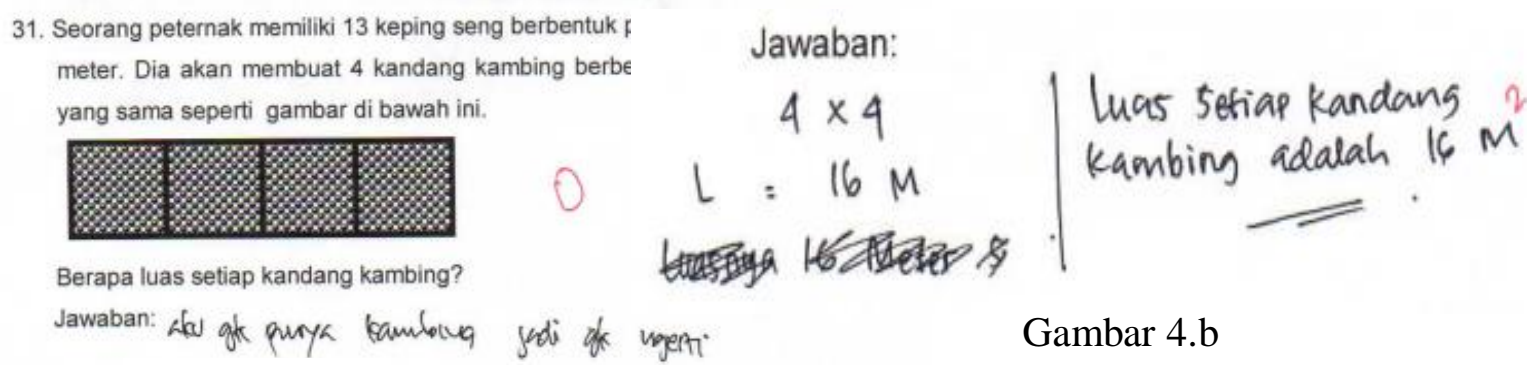

Gambar 4.a

\section{Berapa luas setiap kandang kambing?} Jawaban:
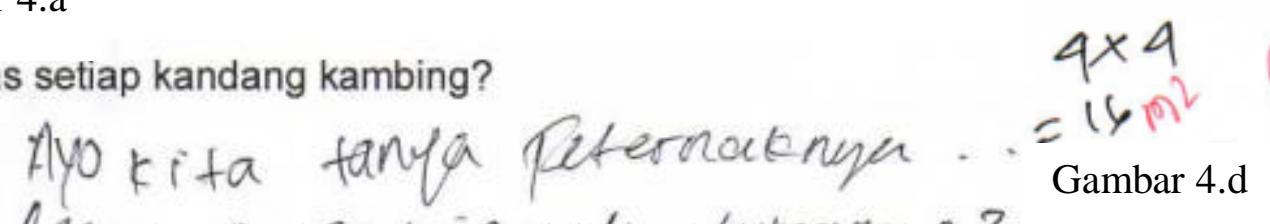

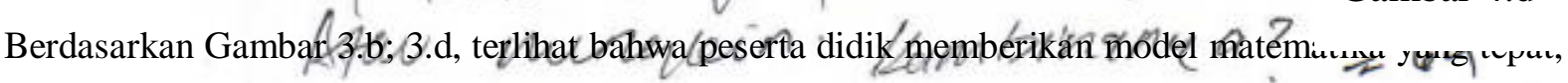
yaitu Luas satu kandang = Giainłbais 4 . eamun peserta didik melupakan satuan yang harus diberikan untuk satuan luas. Namun pada Gambar 3.a, dan 3.c, peserta didik memberikan jawaban yang menunjukkan bahwa peserta didik tersebut tidak mampu menghargai kegunaan matematika dalam kehidupan sehari-hari yang merupakan tujuan dari pembelajaran matematika.

\section{Analisis Soal No 38}

Pada soal nomor 38, memfasilitasi peserta didik untuk menunjukkan kemampuan representasi visualnya. Nomor 38 mengarahkan peserta didik untuk menyajikan kembali data atau informasi dari sebuah grafik yang menunjukkan laju kendaraan minibus dan truk di jalan tol. Melalui soal ini, hanya 48 orang peserta didik yang mampu menjawab dengan tepat, dan memperoleh nilai tinggi, selebihnya peserta didik tidak mampu memberikan jawaban yang tepat terhadap permasalahan yang disajikan.

\section{Analisis Soal No 39}

Soal nomor 39 merupakan soal yang menyajikan materi kesebangunan. Pada soal ini kembali diasah kemampuan representasi peserta didik. Berdasarkan analisa lembar jawaban peserta didik, diperoleh data bahwa peserta didik lupa memasukkan nilai dari kesebangunan ke dalam persamaan matematika. Peserta didik hanya berpendapat karena sisi CF $=$ DF maka perbandingannya 1:1. Ada juga peserta didik yang menyatakan $\mathrm{DF}=\mathrm{BF}$ melalui teori kesebangunan, namun langsung mensubtitusikan ke persamaan $D F=C F$ yang artinya $D F=B F$ dan diperoleh perbandingan 6:4= 3: $2=1$,5. Dari 120 orang pesertadidik 99 orang peserta didik menjawab tidak tepat permasalahan yang diberikan sehingga mendapatkan nilai rendah, dan selebihnya yaitu 21 orang peserta didik mendapat nilai sedang dikarenakan tidak menuliskan langkah dengan lengkap.

\section{KESIMPULAN}

Berdasarkan hasil analisi data diperoleh kesimpulan sebagai berikut

1. Kemampuan representasi visual dari penyajian tabel, peserta didik sudah mampu menyajikan kembali data atau informasi dari suatu tabel menjadi bentuk lain seperti pola barisan. Karena 
peserta didik sudah mempelajari materi barisan dan deret. Pada representasi ini terdapat bermacam bentuk atau pola yang diberikan sehingga menunjukkan kemampuan representasi visual yang baik

2. Kemampuan representasi visual gambar dimana peserta didik membuat gambar bagian-bagian geometri untuk menyelesaikan permasalahan dan memfasilitasi penyelesaian masalah. Berdasarkan lembar jawaban peserta didik, peserta didik sudah mampu membuat gambar geomertri dengan baik. Membuat gambar segitiga dengan tepat. Kendalanya hanya pada pemakaian sifat-sifat dari segitiga tersebut.

3. Kemampuan representasi simbolik atau persamaan atau ekspresi matematika yang dimiliki peserta didik sudah dimiliki hampir sebagian peserta didik. Dari 120 orang peserta didik 50 orang sudah mampu membuat model matematika dengan tepat. Model matematika dalam hal ini berupa rumus luas persegi. Peserta didik sudah mampu melaksanakan penyelesaian masalah dengan menggunakan rumus luas persegi tersebut yang dikategorikan ke dalam model matematika atau ekspresi matematika. Sedangkan 70 orang peserta didik lainnya, tidak bisa mengubah permasalahan yang diberikan menjadi persamaan atau model matematika yang diinginkan.

4. Berdasarkan analisis lembar jawaban pada soal yang dikategorikan representasi verbal diperoleh kemampuan verbal (kata-kata atau teks tertulis) yang dimiliki sebagai besar peserta didik sudah baik. Peserta didik tersebut sudah mampu menuliskan langkah-langkah penyelesaian dengan baik dan teratur.

5. Berdasarkan analisis lembar jawaban peserta didik, diketahui pada soal yang juga dikategorikan soal pemecahan masalah peserta didik mengalami kesulitan dalam membuat situasi masalah berdasarkan data atau representasi yang diberikan serta membuat persamaan atau model matematis dari representasi yang diberikan.

\section{DAFTAR PUSTAKA}

H, Hendriana., E,E Rohaeti., U Sumarmo.(2017) Hard Skills dan Soft Skill Matematik Peserta Didik, 60.

NCTM. (2000). Principles and Standars for School Mathematics. Reston VA : NCTM.

Neria, D dan Amit, M. (2004). Students Preferene of Non Algebraic Representations in Mathematical Communication. Proceedings of the $28^{\text {th }}$ Conference of the International Group for The Psychology of Mathematical Education, 2004, Volume 3, Hlm. 409 - 426.

Syafri, Fatrima Santri. (2017). Kemampuan Representasi Matematis dan Kemampuan Pembuktian Matematika. Jurnal Edumath, Volume 3 Nomor 1, Januari 2017, Hlm. 49 - 55.

Sabirin, Muhammad. (2014). Representasi Dalam Pembelajaran Matematika. JPM IAIN Antasari. Volume 01 Nomor 02Januari - Juni 2014.

S Sugiyono, Metode Penelitian Pendidikan Pendekatan Kuantitatif, kualitatif, dan R\&D, 207, 2010. 
Wiryanto. (2015). Abstraksi Siswa Sekolah Dasar dalam Representasi Konsep Pecahan Melalui Tahap Perkembangan Kognitif Bruner Berdasarkan Perbedaan Gender. Disertasi. Universitas Negeri Surabaya. 